\title{
Development of Innovative Learning Material with Multimedia to Increase Student Achievement and Motivation in Teaching Acid Base Titration
}

\author{
Sinta Puspita Sary \\ Magister in Chemistry Education \\ Postgraduate Program \\ State University of Medan \\ Medan, Indonesia \\ *Corresponding Email: sintapuss.puspita@gmail.com
}

\author{
Simson Tarigan \\ Department of Chemistry \\ Faculty of Mathematics and Natural Sciences \\ State University of Medan \\ Medan, Indonesia
}

\author{
Manihar Situmorang \\ Department of Chemistry \\ Faculty of Mathematics and Natural Sciences \\ State University of Medan \\ Medan, Indonesia
}

\begin{abstract}
The enactment of Indonesian National Qualifications Framework (Kerangka Kualifikasi Nasional Indonesia, KKNI) has prompted Universitas Negeri Medan to implement a competence-based curriculum for every subject taught. The strategy has to be made to bring the students become independent learner by providing suitable learning material. This study aims to obtain innovative learning material with multimedia based project that can improve student achievement and motivation in teaching acid base titration in accordance with the competence required by the KKNI in university. The subjects of the study were students of chemistry majoring who took Basic Analytical Chemistry course divided into two classes, experimental and control class. Experimental class studied by using learning material that has been developed whereas control class with guide ordinary textbook. Innovations to obtain innovative learning material in this research were done by adding some aspects such as media, projects, pictures and video. Type of the research is Research and Development (R\&D). Technique of data analysis in this study is quantitative descriptive. Validator of learning material that has been developed is lecturers of analytical chemistry. Data collection instruments used in this research are questionnaire that contains the standard of teaching material eligibility, motivation questionnaire to know students motivation, objective test to know the improvement of student achievement and the effectiveness of learning material to the student chemistry achievement. The results showed that set of an innovative learning material has successfully develop for teaching acid base titration. The developed learning material meet the eligibility criteria given by the Indonesian National Education Standards Board (BSNP). An innovative leaning package was discovered to be effective to increase student achievement and motivation.
\end{abstract}

Keywords-innovative learning material; multimedia; student achievement; student motivation; acid-base titration

\section{INTRODUCTION}

The development of innovative learning material with multimedia is an action needed for the education sector to improve the quality of education and learning as well as identify, develop and evaluate the content and strategies of learning. Along with the development of science and technology, educators as facilitators must be more creative in developing the learning process, one of which is by innovating in the development of teaching materials, both in terms of technology and applied approaches to be very important for the achievement of learning goals [1]. Learning material is one component that has an important role in improving the quality of education in Indonesia. The need for learning materials is increasingly felt when the number and quality of educators available are not sufficient. Educators have to prepare, implement, and evaluate learning by referring fully to textbooks. Education is a conscious and planned effort to realize a learning atmosphere and learning process so that students actively develop their potential to have spiritual strengths of religion, self-control, personality, intelligence, noble character, and the skills needed by themselves and society [2]. In order to achieve the goals of national education, several efforts have been carried out as a form of change through various activities such as teacher training, change and improvement of curriculum, fulfillment of educational advice and infrastructure, application of school-based management to the provision of remuneration for teachers in accordance with the Laws of Teachers and Lecturers Year 2005 [3].

Changes and improvements to the curriculum are starting from the traditional post-independence curriculum until the modern curriculum has been carried out by the Indonesian people to achieve Indonesia's national education goals. The curriculum is a set of plans and arrangements regarding the 
purpose, content and learning materials as well as ways that are used as guidelines for the implementation of learning activities to achieve certain educational goals [4]. The curriculum that is being developed in general in several Indonesian universities is the Indonesian National Qualification Framework (KKNI). KKNI is a competency qualification level that can compare, equalize, and integrate education and job training in accordance with the work structure in various sectors.

The progress of Science and Technology is one of the factors measuring the development of a nation or state. The emphasis of increasing human resources is in the education environment. The indicator is related to efforts to improve the quality of student learning outcomes in universities. Learning difficulty is a condition experienced by students which is characterized by certain obstacles that cause the achievement of learning goals that have an impact on the final grades of students [5].

The availability of learning materials is a very important thing in delivering good knowledge to students in schools and students in universities. As time goes by and changes in the education system, we need an innovation in the learning materials used. With the innovations made on these learning materials, the delivery of material will be easier to do, Chemistry included in it. Chemistry is one of the compulsory subjects in the faculty of Mathematics and Natural Sciences which is a science that rich in abstract concepts. Chemistry for university is divided into several courses according to their respective fields. For example, in the course of basic analytic chemistry there are several basic materials, one of which is acid-base titration.

Some students considered that if the material is one of the subjects in basic analytical chemistry courses that are considered difficult so that it is not easy to understand. Some of the things that underlie the statement are: (1) systematics and sequence of lessons that have not been able to motivate students to learn because they teach subject matter that is difficult without giving the basic understanding needed, (2) students often learn by memorizing without forming an understanding of chemical material learned, (3) the subject matter taught is floating so students cannot find the 'key' to understanding the lessons learned, and (4) certain teachers are less successful at conveying concepts to students to master the subject matter due to lack in mastering the learning methods [6]. The availability of complete and feasible learning materials for students to use is one that needs to be taken into account in achieving the expected learning goals [7].

The development of important learning materials is carried out by lecturers so that learning is more effective, efficient and does not deviate from the competencies achieved. Innovation is needed in the application of models and methods of learning chemistry that are connected to everyday life. In developing modules/learning materials can be collaborated with appropriate learning methods. One of them is by using projectbased learning, especially on acid-base titration material. Project-based learning is learning that in the execution of project work, students can directly apply all the knowledge and skills in the real setting. Multimedia is an additional facility that is now widely used, media in learning are all kinds of stimulants and tools provided to encourage students to learn [8]. Multimedia means many media (various kinds of media), in other words multimedia can be interpreted as a set of media which is a combination of several relevant media in relation to instructional objectives [9]. By using models and media that support the motivation and competence of students can increase. Learning innovations to improve student achievement in chemistry subjects need to be done because they relate to improving the quality of graduates in filling chemical fields.

\section{RESEARCH METHOD}

This research is a research and development ( $R \& D$ ) that was modified from the development of learning models Borg \& Gall. Research and development is a research used to produce certain products and test the effectiveness of the product [10]. The products developed are innovative leaching materials using multimedia-based projects on learning acidbase titrations in universities.

This research was conducted in the Department of Chemistry, State University of Medan. The population in this study were all students who were studying Basic Analytical Chemistry courses at the State University of Medan. The sample selection in the study was carried out by using a random sampling technique, which is technique that is carried out randomly without regard to certain elements where each population element must have the same opportunity to be selected as a sample [11]. The sample in this study were S1 students of Chemistry Education in State University of Medan who took 2 classes of Basic Analytical Chemistry. This research was carried out through several stages, namely: (1) the development of learning materials using projects, worksheets and multimedia, (2) standardization of innovative learning materials developed using the BSNP standard questionnaire with the help of expert validators namely lecturers of chemistry at the State University of Medan and (3) innovative learning materials that have been developed are given to students, to be tested to determine student motivation, student responses to learning materials that have been developed, improvement of student learning outcomes and the effectiveness of the learning materials.

Data collection instruments used in this are: (1) questionnaire of learning material eligibility containing the feasibility standard of learning materials developed to determine the developed learning materials are suitable for use and to determine student responses to learning materials, (2) motivation questionnaires to see students' motivation after using developed learning materials with multimedia, (3) test objective to determine the improvement of student learning outcomes, (4) the effectiveness of the use of learning materials that have been developed against student chemistry learning outcomes. The data obtained will be tested for reliability, the level of difficulty of the test and the distinguishing power of the objective test.

Data of test objective and learning motivation questionnaire used to investigate the hypothesis testing of student achievement and motivation. Before hypothesis test is 
done, all data obtained must be fulfill requirement is normality and homogeneity test using SPSS 20 for windows program. Normality test analyzed by using Kolmogorov-Smirnov Test while homogeneity test with Independent T-Test.

- Normalized Gain

$$
g=\frac{\text { posttest score-pretest score }}{\text { maximum score-pretest score }}
$$

\section{- Hypothesis Testing}

Hypothesis testing is conducted by using SPSS 20 for windows program of Independent Sample T-Test one tailed ttest at significant level $\alpha=0.05$ with confidence interval $95 \%$, with the criteria, if data obtained is $\operatorname{Sig}_{\text {count }}<0.05$ means the hypothesis of $\mathrm{Ha}$ is received on the contrary the hypothesis of Ho is rejected.

\section{- Percentage Calculation of Student Motivation}

Student motivation in both classes can be obtained by using the formula is:

$\%$ Motivation $=\frac{\text { score of Student's Motivation }}{\text { Total Score of Student's Motivation }} \times 100 \%$

\section{RESEARCH RESULTS AND DISCUSSION}

Data of students' achievement and motivation obtained from experimental and control classes in this research summarized in Tabel 1.

TABEL I. RESULT OF RESEARCH

\begin{tabular}{|c|c|c|}
\hline Class & $\begin{array}{c}\text { Students' } \\
\text { Achievement }\end{array}$ & $\begin{array}{c}\text { Students' } \\
\text { Achievement }\end{array}$ \\
\hline Experimental & $\mathrm{M}=83.00$ & $84.67 \%$ \\
\hline Control & $\mathrm{M}=79.00$ & $78.23 \%$ \\
\hline
\end{tabular}

Students' achievement is obtained from objective test which consist of 25 questions followed by 5 answers choice. This analyzing based on quantitative data with normalized gain. Teaching of acid-base titration in course of basic analytical chemistry showed that students' achievement in experimental class $(\mathrm{M}=83.00)$ is more increase than control class (79.00).

Student's motivation in this research obtained from the score of each student in both class by fill the questionnaire about learning motivation. The questionnaire is using Likert scale, then it can be calculated by using formula of score obtained by student is divided by the total amount of value, the value gotten is presented in the form of percentage (\%).Student motivation is in experimental class is higher (84.67\%) than control class $(78.23 \%)$.

Learning chemistry using multimedia can improve student learning motivation as evidenced by several research reports on learning which state that students are very diligent, strive to complete the project, students feel more passionate in learning and delay in attendance is greatly reduced. Learning innovation is very useful integrated in chemical learning materials, especially to make readers more easily understand and understand the concept of hybrid and complex chemical materials into real and simpler material [12].

Chemical learning innovations also experience development in line with technological advances and developments. Through innovation, the existing learning is developed and improved to produce exciting new learning [13]. Some learning innovations that have been successfully used in chemistry learning are learning innovations using laboratory and non-laboratory activities, learning innovations using media, and information technology-based learning innovations [14].

The use of multimedia in learning materials is interesting because it can integrate various learning media so that it can motivate students to learn independently [15]. Multimedia in science teaching will raises motivation in the form of: 1) the emergence of enthusiasm, interest and involvement, 2) encouraging students to get answers to their interests, 3) students feel a pleasant atmosphere and 4) encourage students to stay focused on the material [16]. The use of multimedia in chemical learning is in line with the demands of chemistry learning that requires high visualization skills for problem solving in chemistry that involves the representation of chemical phenomena in at least three ways, namely: macroscopic, microscopic and symbolic [17].

Learning materials are one of the factors that support the achievement of knowledge or understanding of students both students in schools and students in universities. The learning process in universities prioritizes students to study independently. Students must be more active in their efforts to understand a subject area is not enough just by relying on explanations from lecturers. Therefore, students need other supporting factors to simplify the learning process, where in this study is the Basic Analytical Chemistry course on acidbase titration.

\section{CONCLUSION}

Learning materials are very influential in the learning process of the Basic Analytical Chemistry. The instructional material developed is learning material with multimedia, students not only understand the material theoretically but develop the ability of students to make a material into real work. With learning materials that cover several criteria such as easy to understand, complete in terms of material and feasible from all aspects that must exist in a learning material, learning materials will be very useful for students in the learning process so that it is expected to improve student learning achievement. Based on the research conducted, student learning outcomes and student motivation in the Basic Analytical Chemistry course increased in higher coverage. 


\section{REFERENCES}

[1] H. Fitriani, M. Situmorang, A. Darmana, "Pengembangan Bahan Ajar Inovatif dan Interaktif melalui Pendekatan Sainstifik pada Pengajaran Larutan dan Koloid", Jurnal Edukasi Kimia, vol. 2(1), pp. 48-53, 2017.

[2] M. Wena, Strategi Pembelajaran Inovatif Kontemporer, Jakarta: Bumi Aksara, 2009.

[3] M. Situmorang, "Pengembangan Buku Ajar Kimia SMA Melalui Inovasi Pembelajaran dan Integrasi Pendidikan Karakter untuk Meningkatkan Hasil Belajar Siswa", Prosiding Semirata FMIPA Universitas Lampung, pp. 237-246, 2013.

[4] A.A. Marhaeni, Pembelajaran Inovatif dan Assesmen Otentik dalam Rangka Menciptakan Pembelajaran yang Efektif dan Produktif, Makalah Lokakarya Pengusunan Kurikulum dan Pembelajaran Inovatif Universitas Udayana, 2007.

[5] S. Faika dan S. Side, "Analisis Kesulitan Mahasiswa dalam Perkuliahan dan Praktikum Kimia Dasar di Jurusan Kimia FMIPA Universitas Negeri Makassar”, Jurnal Kimia, vol. 12(2), 18-20, 2011.

[6] M. Situmorang, M. Sitorus, W. Hutabarat dan Z. Situmorang, (2015), "The Development of Innovative Chemistry Textbook to Improve Students Achievement of Bilingual Senior High School Students", International Educational Studies, 2015.

[7] I. Addiin, T. Redjeki dan S.R.D. Ariani, "Penerapan Model Pembelajaran Project Based Learning (PjBL) pada Materi Pokok Larutan Asam dan Basa di Kelas XI IPA 1 SMA Negeri 2 Karanganyar Tahun Ajaran 2013/2014", Jurnal Pendidikan Kimia, vol. 3(4), pp. 125 129, 2014.

[8] S. Tarigan, Pengantar Teori Kurikulum, Medan: Pascasarjana UNIMED, 2012.

[9] F. Eliza, "Pengembangan Bahan Ajar Berbasis Multimedia Interaktif Mata Kuliah Gambar Listrik yang Menggunakan Autocad pada Program Studi Pendidikan Teknik Elektro FT UNP”, Jurnal Teknologi Informasi dan Pendidikan, vol. 6(2), pp. 63-89, 2013.
[10] Sugiyono, Metode Penelitian Pendidikan Pendekatan Kuantitatif, Kualitatif, dan R \& D, Bandung: Alfabeta, 2013.

[11] N.S. Sukmadinata, Metode Penelitian Pendidikan, Bandung: PT Remaja Rosdakarya, 2008

[12] K. Goto, H. Pelto, D.L. Pelletier dan J.S. Tiffany, (2010), "It Really Opened My Eyes: The Effect on Youth Peer Educators of Participating in an Action Research Project, Human Organization", vol. 69(2): pp. 192-200, 2010.

[13] E. Dolan, "Recent Research in Science Teaching and Learning", CBELife Science Education, vol. 8(3), pp. 162-164, 2009.

[14] M. Situmorang, M. Sinaga, D.A. Tarigan, C.J. Sitorus dan A.M.L. Tobing, "The Affectivity of Innovated Chemistry Learning Methods to Increase Student's Achievement in Teaching of Solubility and Solubility Product", Jurnal Penelitian Bidang Pendidikan, vol. 17(1), pp. 29-37, 2011.

[15] M. Situmorang, M. Sitorus dan Z. Situmorang, "Pengembangan Bahan Ajar Kimia SMA/MA Inovatif dan Interaktif Berbasis Multimedia", Prosiding Semirata 2015 bidang MIPA BKS-PTN Barat, Universitas Tanjungpura Pontianak, 2015.

[16] R. Barton, Teaching Secondary Science with ICT, London: Open University Press, 2004.

[17] J.D. Herron, The Chemistry Classroom: Formulas for Succesful Teaching, Washington, DC: American Chemical Society, 1996. 